\title{
Antigenic and functional characterization of p57 produced by Renibacterium salmoninarum
}

\author{
Gregory D. Wiens ${ }^{1, *}$, Maw-Sheng Chien ${ }^{2, * *}$, James R. Winton ${ }^{2}$, Stephen L. Kaattari ${ }^{3}$ \\ ${ }^{1}$ Department of Molecular Microbiology and Immunology, Oregon Health Sciences University, 3181 SW Sam Jackson Park Rd, \\ Portland, Oregon 97201, USA \\ ${ }^{2}$ Western Fisheries Research Center, 6505 N.E. 65th St, Seattle, Washington 98115, USA \\ ${ }^{3}$ Virginia Institute of Marine Science, College of William and Mary, Gloucester Point, Virginia 23062, USA
}

\begin{abstract}
Renibacterium salmoninarum, the causative agent of bacterial kidney disease, produces large quantities of a 57-58 kDa protein (p57) during growth in broth culture and during infection of salmonid fish. Biological activities of secreted p57 include agglutination of salmonid leucocytes and rabbit erythrocytes. We define the location of epitopes on p57 recognized by agglutination-blocking monoclonal antibodies (MAbs) 4C11,4 H8 and 4D3, and demonstrate that the majority of secreted p57 is a monomer that retains salmonid leucocyte agglutinating activity. The 3 MAbs bound a recombinant, amino-terminal fragment of p57 (211 aa) but not a carboxy-terminal fragment ( $315 \mathrm{aa}$ ) demonstrating that the neutralizing epitopes are located within the amino-terminal portion of $\mathrm{p} 57$. When combinations of the MAbs were used in an antigen capture ELISA, the epitopes recognized by the 3 MAbs were shown to be sterically separate. However, when the same MAb was used as both the coating and detection MAb, binding of the biotinylated detection MAb was not observed. These data indicate that the epitopes recognized by the 3 agglutination-blocking antibodies are functionally available only once per molecule and that native p57 exists as a monomer. Similar ELISA results were obtained when kidney tissues from 3 naturally infected chinook salmon were assayed. Finally, a p57 monomer was purified using anion exchange and size exclusion chromatography that retained in vitro agglutinating activity. A model in which p57 is released from $R$. salmoninarum as a biologically active monomer during infection of salmonid fish is proposed.
\end{abstract}

KEY WORDS: Bacterial kidney disease - Renibacterium salmoninarum - Monoclonal antibody Agglutination - Epitope

\section{INTRODUCTION}

Bacterial kidney disease is a chronic, systemic, granulomatous, and often fatal disease prevalent among juvenile and adult salmonids (Fryer \& Sanders 1981). Bacterial kidney disease is one of the most difficult bacterial diseases to control in salmonid aquaculture facilities due in part to 2 unusual pathogenic mechanisms of the causative agent, Renibacterium salmoninarum (Elliott et al. 1989). First, R. salmoninarum can

\footnotetext{
-E-mail: wiensg@ohsu.edu

-Present address: Department of Veterinary Medicine, National Chung Hsing University, 250 Kuo Kuang Road, Taichung, Taiwan 40227, ROC
}

be vertically transmitted from female fish to offspring via intracellular infection of the egg (Evelyn et al. 1984, 1986). Second, the bacterium can reside intracellularly within salmonid phagocytes and other host cells which may hinder immune clearance (Young \& Chapman 1978, Bruno \& Munro 1986, Gutenberger et al. 1997. McIntosh et al. 1997). Little is known about the molecular mechanisms of pathogenesis or the host immune response (Evenden et al. 1993), however, this knowledge is crucial for the development of more efficacious therapeutics and vaccines

The best characterized virulence factor of Renibacterium salmoninarum is a $57-58 \mathrm{kDa}$ protein ( $\mathrm{p} 57$ ). This protein is exposed on the bacterial cell surface of most strains and is also abundantly secreted by the bacteria during growth in culture media or infection of 
fish (Getchell et al. 1985, Turaga et al. 1987b, Wiens \& Kaattari 1989, Rockey et al. 1991a, Bandin et al. 1992). Cell-associated p57 has been reported to be necessary for virulence as spontaneous mutants of $R$. salmoninarum lacking cell-associated p57 were less virulent upon intraperitoneal challenge (Bruno 1988, 1990). However, whether these mutants completely lack expression of p57 has been questioned (Grayson et al. 1995).

The function of secreted p57 in pathogenesis is unclear and sequence comparison with other proteins has so far been uninformative. P57 is a glycine rich, 557 amino acid protein containing 2 copies of an 81 residue direct repeat, which are $60 \%$ homologous, and 5 copies of a second 25 residue imperfect repeat (Chien et al. 1992). One function of p57 may be to mediate adherence of the bacteria to host tissues. P57 has been reported to form a fimbrial structure on the bacterial cell surface and has a number of other characteristics of bacterial adhesins including haemagglutinating activity, an acidic isoelectric point, and hydrophobic amino acid composition (Jones \& Isaacson 1983, Daly \& Stevenson 1990, Dubreuil et al. 1990a, Wiens \& Kaattari 1991). In vitro, the secreted form of p57 has immunomodulatory effects as it is able to bind and agglutinate salmonid leucocytes and suppress antibody production to the unrelated antigens, trinitrophenylated lipopolysaccharide and human gammaglobulin (Turaga et al. 1987a, Rockey et al. 1991b, and Wiens \& Kaattari 1991, Fredriksen et al. 1997). In addition, injection of coho salmon eggs with $\mathrm{p} 57$ has been reported to result in long term immunosuppression (Brown et al. 1996)

We have previously identified functional domains of p57 using a panel of 8 anti-p57 monoclonal antibodies (MAbs) (Wiens \& Kaattari 1991). Three of the MAbs (4D3, 4H8, and 4C11) inhibit haemagglutinating activity while 2 of these MAbs ( $4 \mathrm{H} 8$ and $4 \mathrm{C} 11$ ) inhibit the leucoagglutinating activity of $\mathrm{p} 57$. The 3 agglutination inhibiting MAbs, referred to as group I MAbs, putativly recognize epitopes located on the aminoterminal third of p57, as determined by amino acid sequencing of p57 and immunoblotting of partial p57 proteolytic digests. Group II MAbs (3H1 and 2G5) recognize epitopes located in the central region of $p 57$, while group III MAbs (1A1,4D10 and 2G9A) recognize epitopes present in the carboxy-terminal third of p57 that are not exposed when intact p57 is attached to the Renibacterium salmoninarum cell surface.

In this study, the functional domains of p57 were further defined. The group I MAbs recognized separate non-overlapping epitopes in an enzyme linked immunosorbent assay (ELISA) and these epitopes were localized on the amino-terminal portion of p57 by immunoblotting of recombinant fragments of $\mathrm{p} 57$. The subunit structure of p57 was also examined with fast pressure liquid chromatography (FPLC) and ELISA and we found that secreted p57 was present as a monomer in culture supernatant as well as infected fish tissue. The monomer, purified from bacterial culture supernatant, was sufficient for agglutination of rabbit erythrocytes and fish leucocytes in vitro.

\section{MATERIALS AND METHODS}

Animals. Rainbow trout Oncorhynchus mykiss were held in $12^{\circ} \mathrm{C}$ well water at the Oregon State University Salmon Disease Laboratory and were fed Oregon Moist Pellets (Bioproducts, Warrington, OR). Samples of infected kidney tissue were obtained from spawning spring chinook salmon (O. tshawytscha) at Marion Forks Hatchery, OR, and Carson Hatchery, WA, and homogenized as previously described (Rockey et al 1991a).

Purification of MAbs. Cell-free ascites fluid from group I MAbs (4C11,4H8, and 4D3), group II MAbs (2G5 and 3H1) and group III MAbs (1A1 and 4D10) were collected and purified by protein A chromatography as described previously (Wiens \& Kaattari 1991). Protein content was determined by the method of Lowry et al. (1951).

Extracellular protein (ECP) concentration. Renibacterium salmoninarum ATCC 33209 extracellular protein was harvested from medium and concentrated as described previously (Wiens \& Kaattari 1991). The predominant component of ECP prepared in this manner is p57 with associated proteolytic degradation fragments (Rockey et al. 1991b, Wiens \& Kaattari 1991). Total protein was assessed by the method of Lowry et al. (1951) using bovine serum albumin (BSA, Sigma, St. Louis, MO) as a standard. The ECP was filter-sterilized $(0.45 \mu \mathrm{m})$ and stored at $-70^{\circ} \mathrm{C}$ or kept at $4^{\circ} \mathrm{C}$ for immediate use.

ELISA. A capture ELISA was performed as described previously (Wiens \& Kaattari 1989). Briefly, in this assay $5 \mu \mathrm{g} \mathrm{ml}^{-1}$ MAbs $4 \mathrm{D} 3,4 \mathrm{H} 8,4 \mathrm{C} 11$, or polyclonal rabbit anti-ECP were separately coated onto the plate, non-specific sites blocked with $1 \%$ BSA - 0.1\% Tween-Tris buffered saline (TTBS; $50 \mathrm{mM}$ Tris, $1 \mathrm{mM}$ EDTA, $8.7 \% \mathrm{NaCl}, \mathrm{pH} 8.0$ ), and then $5 \mu \mathrm{g} \mathrm{m}{ }^{-1} \mathrm{ECP}$ in $0.1 \%$ TTBS was added. After washing the wells, $5 \mu \mathrm{g}$ $\mathrm{ml}^{-1}$ of a biotinylated detection MAb was added as a probe to screen for available epitopes on p57. Streptavidin-horseradish peroxidase (Sigma) was then added to determine the amount of bound biotinylated antibody. To measure non-specific binding, biotinylated MOPC-21, a $\operatorname{IgG}_{1}$, K MAb of unknown specificity, was used as a negative control (Sigma). Formalin-fixed Renibacterium salmoninarum cells were used as a 
positive control to show that aggregates of p57 could be detected by the ELISA. R. salmoninarum cells were fixed for $12 \mathrm{~h}$ with $0.3 \%$ formalin, washed $3 \times$ in phosphate buffered saline (10 $\mathrm{mM}$, PBS, pH 7.2), and resuspended at a concentration of $50 \mu \mathrm{g}$ wet wt $\mathrm{ml}^{-1}$ of $1 \%$ BSA in $0.1 \%$ TTBS.

Purification of p57. FPLC was used to purify p57 from ECP. Prior to FPLC, ECP was dialyzed in $50 \mathrm{mM}$ phosphate buffer ( $\mathrm{pH} 7.2)$ and filtered through a $0.2 \mu \mathrm{m}$ low protein binding filter (Acrodisc 13, Gelman Sciences, Ann Arbor, MI). Approximately $3.9 \mathrm{mg}$ of protein was loaded onto a HR 5/5 Mono $Q$ anion exchange column and eluted with a biphasic salt gradient of 0 to $0.6 \mathrm{M} \mathrm{NaCl}$, followed by 0.6 to $1.0 \mathrm{M} \mathrm{NaCl}$ in $50 \mathrm{mM}$ phosphate buffer ( $\mathrm{pH} 7.2$ ). One milliliter fractions from the anion exchange column were stored at $-70^{\circ} \mathrm{C}$ until analyses were performed. A biphasic salt gradient eluted approximately $70 \%$ of the total protein in fractions 1 to 30 (see Fig. 3A).

To determine the native molecular weight of $\mathrm{p} 57$. fraction 6 ( $75 \mu \mathrm{g}$ total protein) from the anion exchange column was separated on a HR 10/30 Superose 12 FPLC gel filtration column $(10 \times 30 \mathrm{~cm}$, Pharmacia $)$ using a buffer of $50 \mathrm{mM} \mathrm{NaCl}, 50 \mathrm{mM}$ phosphate ( $\mathrm{pH}$ 7.2) and $1 \mathrm{mM}$ phenylmethylsulfonyl fluoride protease inhibitor (PMSF). The peak absorbing fraction (15) from the gel filtration column was concentrated 12 -fold by ultrafiltration using a Centricon-3 (3000 MW cutoff, Amicon Division, Grace and Co., CT).

Protease assay. The protease assay adapted from Sarath et al. (1989) used filter sterilized substrate solution of $2 \%$ azoalbumin (Sigma) in a $0.1 \%$ sodium dodecyl sulfate, $10 \mathrm{mM}$ phosphate, $7.5 \% \mathrm{NaCl}$ buffer (pH 7.2). Protease activity was determined by mixing $30 \mu \mathrm{l}$ of each column fraction with $50 \mu \mathrm{l}$ of substrate at an incubation temperature of $37^{\circ} \mathrm{C}$ for $15 \mathrm{~h}$. Intact substrate was precipitated with $200 \mu \mathrm{l}$ of $10 \%$ trichloroacetic acid for 15 min at room temperature. Samples were microfuged for $5 \mathrm{~min}$, and $100 \mu \mathrm{l}$ of supernatant was transferred to ELISA wells to which $100 \mu 1.0 \mathrm{M}$ $\mathrm{NaOH}$ was added. The $\mathrm{A}_{450}$ (absorbance at $450 \mathrm{~nm}$ ) was determined using an EIA autoreader (Biotek Instruments, Burlington, VT). Units of activity were calculated from a log-log plot using trypsin (\#T2271, Bovine Pancreas, Sigma) as a standard.

Leucoagglutination and haemagglutination assays. Rainbow trout leucocytes and rabbit erythrocytes were prepared as previously described (Wiens \& Kaattari 1991), except that leucocytes were resuspended to a final concentration of $2 \%$ autologous plasma (DeKoning \& Kaattari 1991) instead of $10 \%$ fetal bovine serum. Agglutination reactions worked equally well in either serum source. A total of $1.0 \times 10^{6}$ leucocytes well ${ }^{-1}$ or $1.5 \times 10^{6}$ erythrocytes well ${ }^{-1}$ were mixed with $50 \mu \mathrm{l}$ of column fraction or 2 -fold dilutions of each fraction.
Agglutination was assessed after $24 \mathrm{~h}$ by microscopic examination.

Construction and expression of recombinant, truncated p57 fragments. A 636 nt EcoRI to Xhol fragment encoding amino acids 32 to 243 of p57 was subcloned into pET-22b(+) (Novagen, Madison, WI). A second construct containing the carboxy-terminal amino acids 242 to 557 was generated by PCR amplification with the reverse primer 5'-CGCGCTCGAGGTTAAAGGTAATATCTAT and a forward primer 5'CCGACAGCAACTCTCGAGCCT. Hot start PCR amplification was carried out as recommended (Perkin Elmer, Norwalk, CT) using $5 \mathrm{U}$ of Ultma polymerase and $750 \mathrm{ng}$ of target DNA. Twenty amplification cycles $\left(94^{\circ} \mathrm{C}, 30 \mathrm{~s} ; 55^{\circ} \mathrm{C}\right.$, $2 \min ; 72^{\circ} \mathrm{C}, 3 \mathrm{~min}$ ) were followed by $10 \mathrm{~min}$ at $72^{\circ} \mathrm{C}$. Following $\mathrm{PCR}$, the product was purified and digested with XhoI and the $946 \mathrm{bp}$ fragment subcloned into $\mathrm{pET}$ $22 \mathrm{~b}(+)$ expression vector and confirmed by sequencing. Both constructs were expressed according to the protocol supplied with the pET22b(+) vector (Novagen). Briefly, the constructs were transformed into E. coli BL 21 and grown to an O.D. of $0.6(600 \mathrm{~nm})$. The expression of the His-tag fusion proteins was induced with $1 \mathrm{mM}$ IPTG for $2 \mathrm{~h}$. Bacterial cells were washed in $50 \mathrm{mM}$ Tris, pH 8.0,2 mM EDTA, and stored as a pellet at $-70^{\circ} \mathrm{C}$. Thawed cells were resuspended 1:4 wt: vol in $50 \mathrm{mM}$ Tris, $\mathrm{pH}$ 8.0, 2 mM EDTA, and $40 \mu$ of this suspension was mixed with $10 \mu l 1 \mathrm{M}$ DTT and $50 \mu \mathrm{l} 2 \times$ SDS-PAGE sample buffer. Samples were boiled for $3 \mathrm{~min}$, and sonicated for $2 \mathrm{~s}$ (Heat System Ultra Sonicator Inc.). Standard 10 or $12 \%$ SDS-PAGE and Western blotting were performed as previously described using the Mini-PROTEAN II system (BioRad) (Wiens et al. 1990).

\section{RESULTS}

\section{Epitope identification using group I MAbs}

In order to characterize the functional domains of p57 we used an antigen capture ELISA to determine if the epitopes recognized by the group I antibodies are distinct. Results from these experiments indicated that each of the 3 MAbs recognized spatially distinct epitopes (Fig. 1A,B,C). For example, when 4D3 was coated onto wells, both heterologous biotinylated antibodies $4 \mathrm{H} 8$ (4H8-B), 4C11-B as well as polyclonal rabbit antisera (RB-B) bound to $\mathrm{p} 57$, while the homologous antibody (4D3-B) and negative control MAb MOPC 21-B did not bind (Fig. 1A). Analogous results were obtained using the $4 \mathrm{H} 8$ and $4 \mathrm{C} 11$ MAbs (Fig. 1B,C). Some binding of 4C11-B to p57 captured by $4 \mathrm{C} 11$ was observed, but was apparently nonspecific in nature as the level was similar to that ob- 
served using the negative control antibody MOPC21-B. Equivalent activity of each biotinylated antibody was demonstrated by its binding to ECP coated wells (Fig. 1D).

\section{Expression of a recombinant p57}

To independently localize the epitopes recognized by the group I MAbs, the amino-terminal portion of p57 and a carboxy-terminal portion of p57 were expressed in E. coli BL21 with a pel-B leader and Histag (Fig. 2A). The amino terminal fragment, designated p57.NH2, contained amino acids 32 to 243 and included amino acid repeat $\mathrm{A} 1$. The carboxy-terminal fragment of p57, designated p57.COOH, contained amino acids 242 to 557 including amino acid repeat A2 and repeats B1-5. Expression of p57.NH2 and p57.COOH in E. coli was induced with IPTG and detected by Coomassie Blue staining of SDS-PAGE gels (Fig. 2B). MAb recognition of the recombinant proteins was assessed by immunoblotting. Group I MAb, 4H8, bound the amino-terminal fragment (Fig. 2B, lane 2), but not the carboxy-terminal fragment (lane 3). MAbs 4C11 and 4D3 showed a similar binding pattern (data not shown). Lack of binding to the car- boxy-terminal fragment containing repeat A2 suggests that the group I antibodies do not recognize shared epitopes located on repeat $A 1$ and $A 2$. Conversely, group II (MAb 2G5) and group III (MAb 1A1) antibodies recognized epitopes on the carboxy-terminal fragment (Fig. 2B, lane 3 ) but not the amino-terminal fragment (lane 2). MAbs 3H1 and 4D10 showed a similar binding pattern (data not shown). The expression of $\mathrm{p} 57 . \mathrm{COOH}$ produced several immunoreactive bands that presumably represent proteolytic degradation products consistent with the previously observed proteolysis of recombinant p57 expressed in E. Coli (Grayson et al. 1995).

\section{Purification of p57 from culture supernatant and analysis of agglutinating activity}

To determine the subunit structure of p57 we used chromatographic methods to purify p57 from ECP. First, ECP was separated on an anion exchange mono$\mathrm{Q}$ column. The majority of protein was eluted in the first 5 fractions as determined by absorbance at $280 \mathrm{~nm}$ (Fig. 3A). P57 was the major component eluting in fractions 5 through 14 as determined by total protein staining of transblotted proteins from SDS-PAGE gels
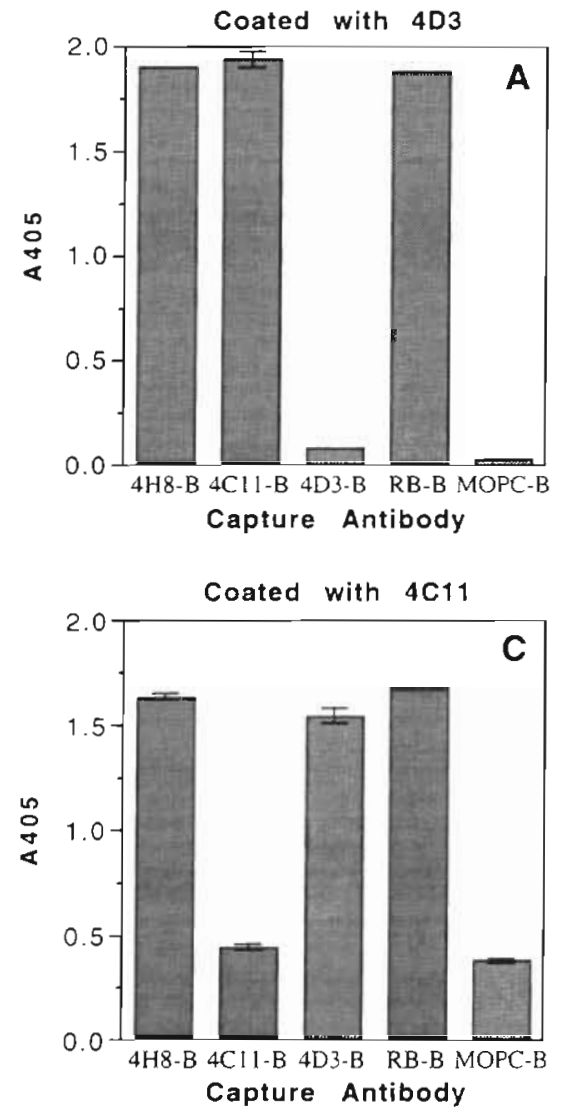
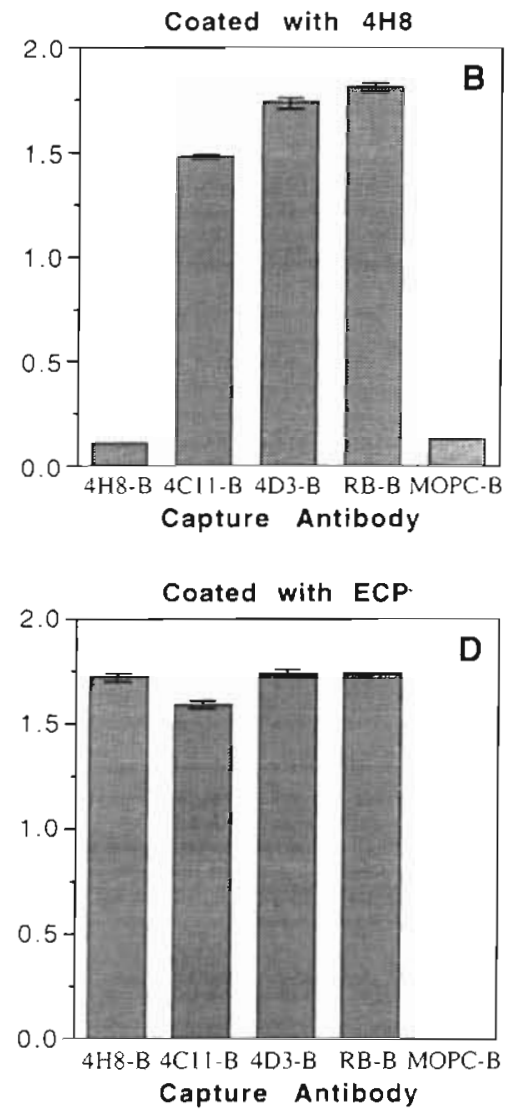

Fig. 1. ELISA epitope analysis using combinations of group I MAbs, 4D3, $4 \mathrm{H} 8$, and $4 \mathrm{C} 11$. Antibody was coated onto the ELISA plate at $5 \mu \mathrm{g} \mathrm{m} \mathrm{m}^{-1}$ followed by $5 \mu \mathrm{g} \mathrm{ml}^{-1}$ ECP diluted in $0.1 \%$ TTBS. Biotinylated detection MAbs $\left(5 \mu \mathrm{g} \mathrm{ml}^{-1}, \mathrm{MAb}-\mathrm{B}\right)$ were used to determine the steric availability of epitopes. Biotinylated rabbit anti-ECP sera (RB-B) was used as a positive control, and biotinylated MAb MOPC 21 (MOPC-B) was used as a negative control to detect nonspecific binding. ECP was coated directly onto the ELISA plate to determine maximal binding of each biotinylated antibody. After substrate was added, plates were incubated for $30 \mathrm{~min}$ before $\mathrm{A}_{405}$ was measured. Error bars denote standard deviations of triplicate wells. Similar results were obtained in 3 separate experiments 
(Fig. 3B). The identity of p57 in these fractions was further confirmed by Western blotting using MAb $1 \mathrm{~A} 1$ (Fig. 4B) and MAb 4D3 (not shown). Column fractions were also tested for haemagglutinating activity, proteolytic activity, and immunoreactivity by ELISA. Fractions 4 through 15 possessed haemagglutinating activity correlating with the elution of p57 (Fig. 4A). Proteolytic activity, detected by azoalbumin degradation, was also observed in ECP and a major peak of activity eluted in fraction 3 prior to fractions in which the majority of p57 was found (Fig. 4A). In addition, minor amounts of proteolytic activity were observed in fractions 10 through 15 . Proteolytic activity was undetectable in fraction 6 which was used for further molecular weight characterization.

To determine the native molecular weight of $\mathrm{p} 57$. $75 \mu \mathrm{g}$ of fraction 6 from the anion exchange column was subjected to superose size exclusion chromatography. Dextran blue $(30 \mu g)$ was included as an internal marker. Two peaks were detected by $\mathrm{A}_{280}$ absorbance, the first peak was dextran blue at $7.5 \mathrm{ml}$ and the second peak eluted at a peak of $14.3 \mathrm{ml}$
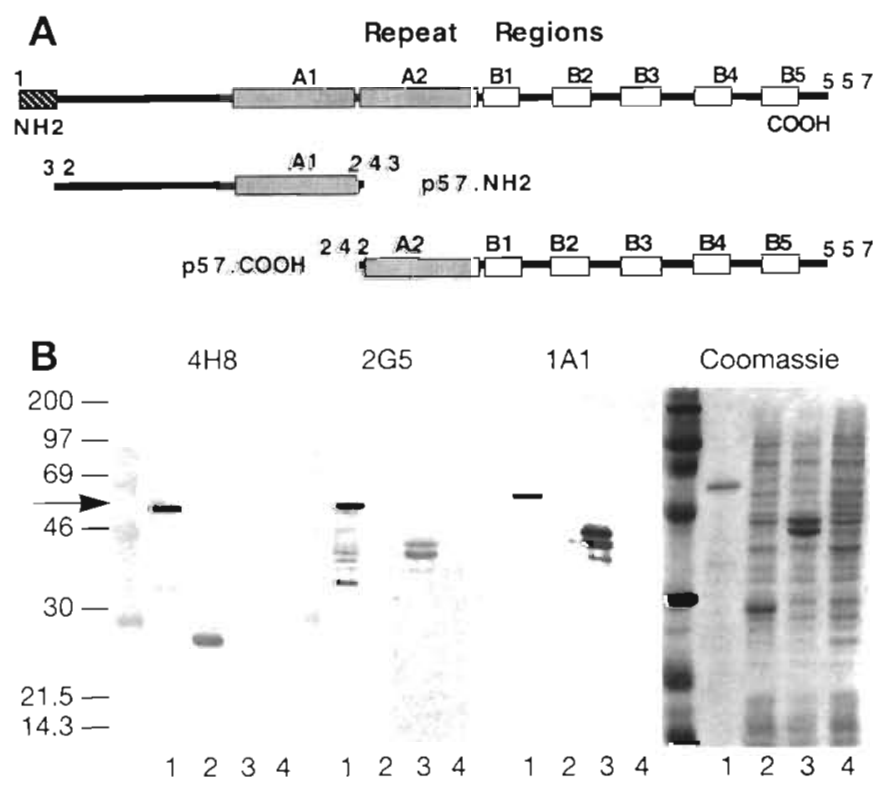

Fig. 2. (A) Linear depiction of native p57 protein including repeated regions. The larger repeat consists of two 81 residues segments $A 1$ and $A 2$, and the smaller repeated sequence consists of 5 non-identical repeats of approximately 25 residues each (B1 through B5). Two fragments of p57 were expressed from a pET-22b vector in $E$. coli strain BL21. An amino-terminal fragment from amino acid 32 to 243 (p57.NH2) and a carboxy-fragment from amino acid 232 to 557 (p57.COOH). (B) Immunoblots and Coomassie blue stain of recombinant proteins probed with either group I MAb 4H8, group II MAb 2G5, or group III MA.b 1A.1. Lanes after the molecular weight markers are as follows: $1,1 \mu \mathrm{g}$ ECP, 2, p57.NH2, 3, p57.COOH, 4, Induced E. coli control. Intact p57 is identified with an arrow

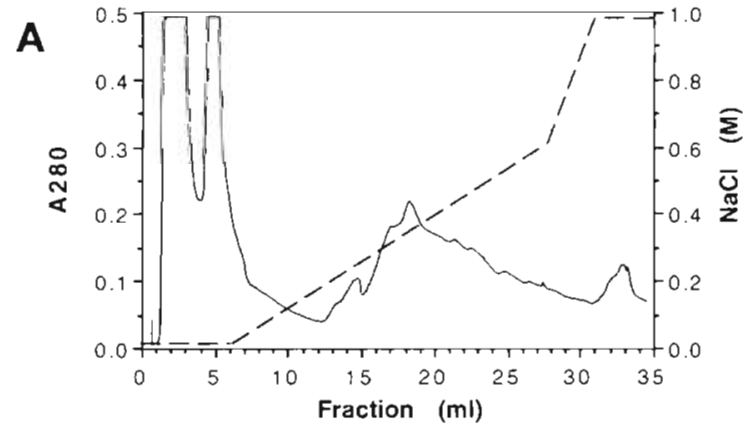

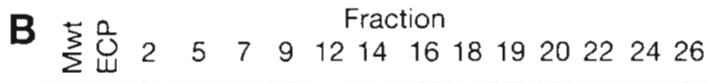

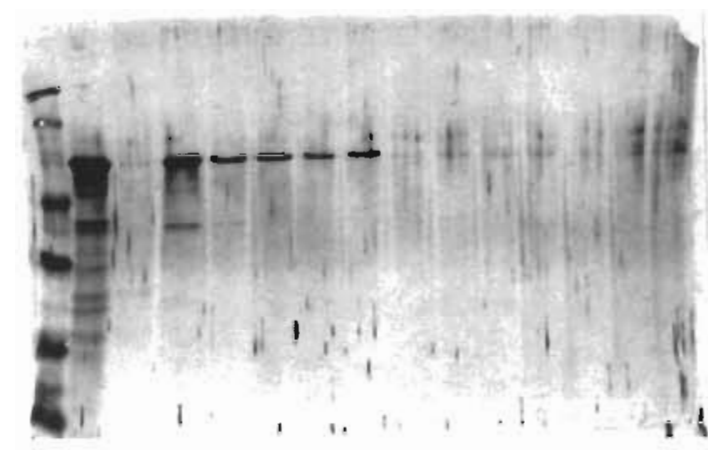

Fig. 3. (A) FPLC anion-exchange chromatography of concentrated culture supernatant (ECP) from Renibacterium salmoninarum ATCC 33209. ECP (protein content $3.9 \mathrm{mg}$ ) was applied to a anion-exchange Mono-Q column (HR 5/5) and eluted with a biphasic $\mathrm{NaCl}$ gradient in a $50 \mathrm{mM}$ phosphate

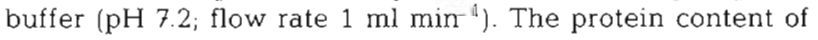
the eluent was detected photometrically at $280 \mathrm{~nm}$ with a UV monitor (solid line). A linear salt gradient of 0 to $600 \mathrm{mM}$ was used to elute proteins from fraction 6 to 28 (dotted line). A 600 to $1000 \mathrm{mM}$ salt gradient was used from fraction 28 to 32 . (B) Total protein stain of FPLC anion exchange column fractions 2 through 26. A total of $2.5 \mu \mathrm{l}$ of each fraction was electrophoresed through a $10 \%$ SDS polyacrylamide gel and electroblotted onto nitrocellulose and total protein detected with a collodial gold stain. The results are representative of 2 experiments

(Fig. 5A). The second peak contained p57 as determined by a highly sensitive ELISA, and the majority of immunoreactivity eluted in fractions 14 through 17. Estimation of relative molecular weight of p57 using a panel of known proteins indicated that p57 eluted as a monomer with a calculated relative migration of 46500 Da (Fig. 5B), as opposed to a dimer or multiaggregated protein which should have eluted prior to fraction 13. Fraction 15 was further concentrated and subject to electrophoresis and immunoblotting (Fig. 6). P57 was purified to near homogeneity (Fig. 6, lane 3), excluding a small amount of $\mathrm{p} 45$, as compared to the starting material (Fig. 6, lane 1). The minimum concentration required for agglutinating activity of rainbow trout leucocytes was decreased from $25 \mu \mathrm{g} \mathrm{ml} l^{-1}$ of the 

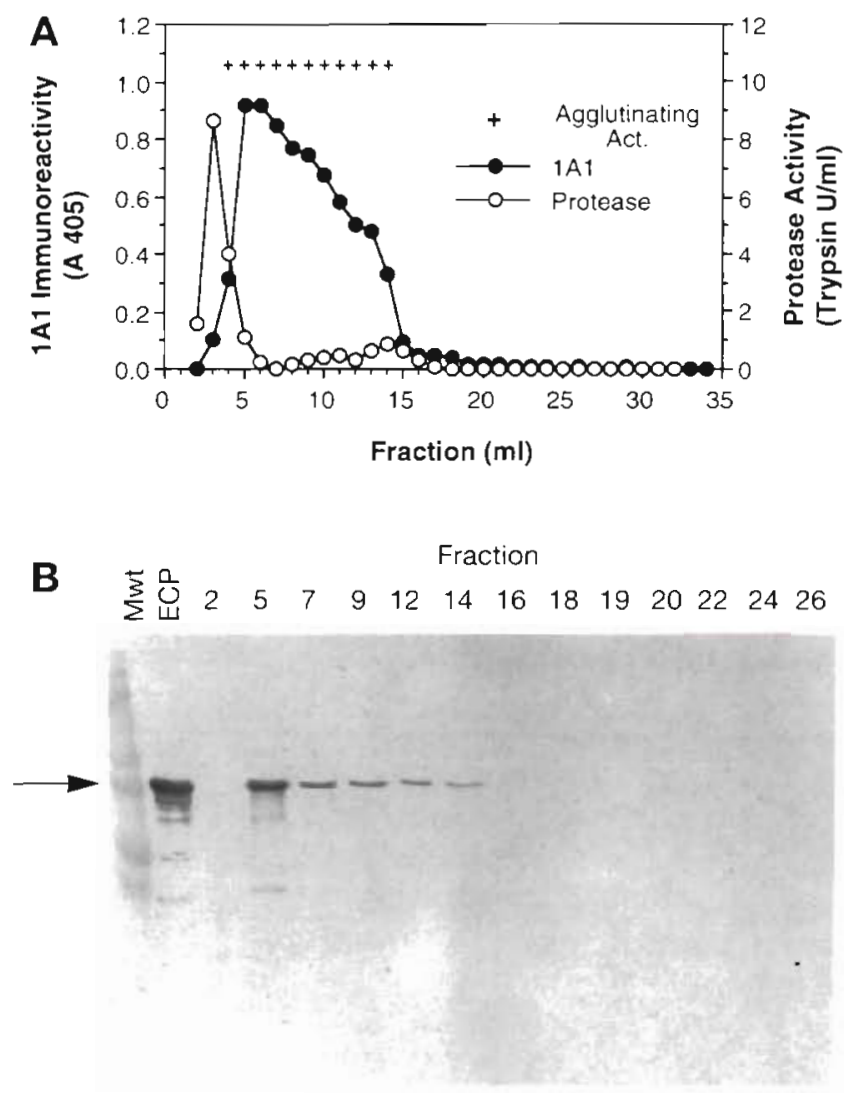

Fig. 4. Agglutinating, proteolytic, and immunoreactive properties of the anion-exchange column fractions. (A) Fractions with agglutinating activity for rabbit erythrocytes are indicated with a + . Column fractions were coated onto ELISA wells and immunoreactivity probed with MAb $1 \mathrm{~A} 1(\bullet)$. Proteolytic activity against azoalbumin was measured as described in 'Materials and methods' (O). (B) Western blot of column fractions using MAb $1 \mathrm{~A} 1$. Intact $\mathrm{p} 57$ is identified with an arrow
ECP to $12.5 \mu \mathrm{g} \mathrm{ml}^{-1}$ of purified p57 indicating an approximately 2 -fold increase in activity. Agglutination of rabbit erythrocytes was also observed with purified p57. Agglutinating activity could be completely blocked with $100 \mu \mathrm{g} \mathrm{ml}^{-1} \mathrm{MAb} 4 \mathrm{H} 8$ confirming that agglutination was mediated by $\mathrm{p} 57$.

\section{Capture ELISA analysis of p57 in infected fish tissues}

To investigate whether monomers of p57 were present in infected fish tissue, we performed capture ELISA analysis on kidney homogenates from naturally infected adult chinook salmon. Similar to the analysis shown in Fig. 1, p57 captured by MAb 4D3 was not recognized by the homologous biotinylated MAb $4 \mathrm{D} 3$ but was recognized by the heterologous MAb $4 \mathrm{H} 8-\mathrm{B}$ (Fig. 7). Formalin-fixed bacteria were used as a positive control to demonstrate that the combination of MAb 4D3 and 4D3-B could detect aggregates of p57. It is unclear why MAb 4D3-B showed less binding to the formalin-fixed bacterial cells at concentrations equivalent to those used with $\mathrm{MAb} 4 \mathrm{H} 8-\mathrm{B}$, but perhaps this was due to steric hindrance from the coating MAb 4D3 or destruction of epitopes by formalin.

\section{DISCUSSION}

To elucidate the molecular mechanisms of Renibacterium salmoninarum pathogenesis, we utilized mouse MAbs to characterize the structure and function of a major cell surface and secreted protein, p57. In this study, we extend our previous epitope map of p57 and investigate the mechanism of cell agglutination. Previ-
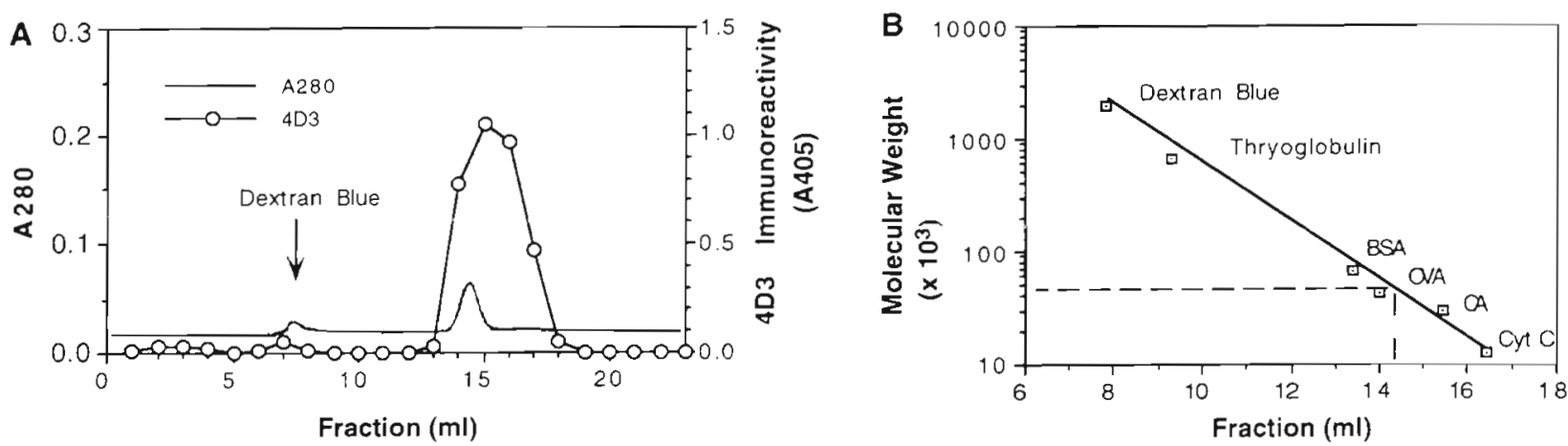

Fig. 5. (A) Size exclusion chromatography of anion exchange fraction number $6(75 \mu \mathrm{g})$, using a Superose 12 column. Dextran blue $(30 \mu \mathrm{g})$ was included as an internal standard. (B) Relative migration of proteins vs log molecular weight markers. The column was equilibrated. with $50 \mathrm{mM}$ phosphate and $50 \mathrm{mM} \mathrm{NaCl}, \mathrm{pH} 7.2$, and Sigma standards were used to calibrate the column. Each point represents the average elution time and standard deviation calculated from 3 separate experiments. Standards included dextran blue $(2000000)$, thryoglobulin $(669000)$, bovine serum albumin $(66000)$, ovalbumin (43000), carbonic anhydrase (29000) and cytochrome $\mathrm{C}(12400)$. The dashed line represents the calculated molecular weight for p57. Identical results were obtained with 2 separate 057 preparations 


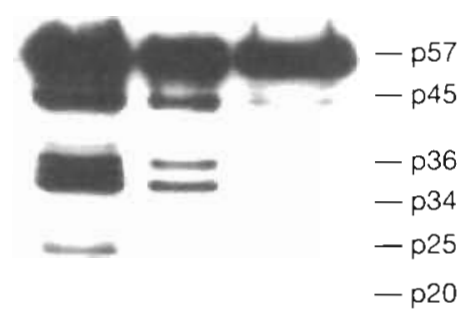

Fig. 6. Immunoblot of column purified p57. The immunoblot was probed with $1 \mu \mathrm{g} \mathrm{ml}^{-1}$ of a pool of purified MAbs 4D3, $3 \mathrm{H} 1$, and $1 \mathrm{~A} 1$. Primary MAb was detected by a 1:4000 goat anti-mouse Ig HRPO conjugate. The blot was developed with a chemiluminescent substrate (Amersham) and exposed to film for 1 min. Lanes: $1, E C P, 1 \mu \mathrm{g} ; 2,2.5 \mu \mathrm{l}$ of FPLC Mono-Q fraction $6 ; 3,7.5 \mu$ of $12 \times$ concentrated Superose 12 fraction 15

ously, we found that 3 MAbs, 4H8, 4C11 and 4D3, inhibit haemagglutinating activity while 2 of these MAbs, $4 \mathrm{H} 8$ and 4C11 also inhibit the leucoagglutinating activity of p57 (Wiens \& Kaattari 1991). To determine if these antibodies recognize the same or distinct epitopes on p57 we used a capture ELISA. In this

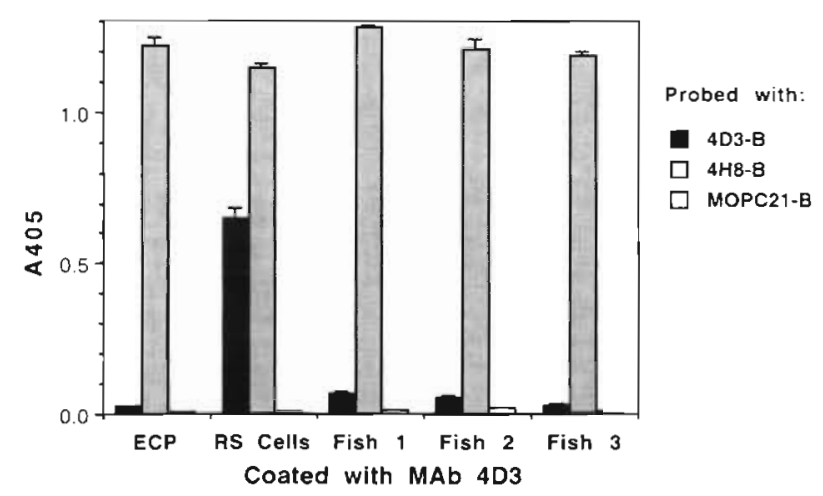

Fig. 7. ELISA epitope analysis of kidney tissue from 3 infected adult chinook salmon which were previously found to have antigen levels above $1 \mu \mathrm{g} \mathrm{ml}^{-1}$ Plates were coated with $5 \mu \mathrm{g}$ $\mathrm{ml}^{-1} 4 \mathrm{D} 3$, blocked with $1 \%$ BSA-TTBS, and either $5 \mu \mathrm{g} \mathrm{m}{ }^{-1}$ ECP, formalin-fixed Renibacterium salmoninarum cells $(50 \mu \mathrm{g}$ $\mathrm{ml}^{-1}$ ), or a 1:100 dilution of kidney tissue homogenate added. ELISA plates were then probed with $5 \mu \mathrm{g} \mathrm{m}^{-1}$ detection MAbs 4D3-B, $4 \mathrm{H} 8-\mathrm{B}$ or MOPC21-B. After substrate was added, plates were incubated for $10 \mathrm{~min}$ before $A_{405}$ was measured. Error bars denote standard deviations of triplicate wells assay, MAb 4D3, 4C11 and 4H8 each recognized a distinct epitope. The locations of the 4D3,4H8 and 4C11 epitopes were confirmed to lie between amino acids 32 to 243 on p57 as all 3 of the MAbs bound the recombinant, amino-terminal fragment, p57.NH2, but not to the carboxy-terminal fragment, p57.COOH, in a Western blot. These findings are consistent with our previous data showing that group I MAbs bind aminoterminal proteolytic fragments of p57 (Wiens \& Kaattari 1991). Also consistent with our previous epitope map, group II MAbs (2G5 and 3H1) and group III MAbs (1A1 and 4D10) bound p57.COOH but not p57.NH2. The demonstration that the 3 group I MAbs recognized separate epitopes, and that these epitopes are separate from epitopes bound by the group II or III antibodies, may have relevance for MAb-based immunodiagnostic assays used to detect p57 in infected salmonids (Hsu et al. 1991, Rockey et al. 1991a). Inclusion of individual or combinations of these MAbs would increase the number of epitopes detected and may thereby increase the sensitivity of these ELISAs.

The capture ELISA assay revealed an interesting aspect of the antigenic structure of p57. We observed that when the same MAb was used for both the coating and detection, binding of the biotinylated detection MAb was not observed. This was not due to a failure of the coating antibody to bind p57 because the heterologous biotinylated MAbs and biotinylated rabbit polyclonal antisera each bound well. This result was the same with each of the 3 group I MAbs suggesting that each epitope was functionally available only once per molecule of $\mathrm{p} 57$. These data are consistent with a monomer structure of p57. A dimer or aggregate of p57, containing 2 or more copies of the same epitope, would allow the simultaneous binding of both the homologous coating and detecting antibody, providing that the epitopes are not masked by dimerization or aggregation. Our failure to detect binding when homologous MAbs were used was not due to an inability to detect aggregates of p57 as 4D3 and biotinylated 4D3 were able to bind formalin-fixed Renibacterium salmoninarum cells that contain multiple copies of $p 57$. The absence of repeated epitopes was surprising as Barton et al. (1997) have recently reported aggregation of p57 occurred after separation by SDS-PAGE and elution with SDS and Triton X-100. In addition, we have observed MAb immunoreactive bands much larger than $57 \mathrm{kDa}$ in ECP preparations resolved under reducing SDS-PAGE conditions (Wiens \& Kaattari 1991). It is possible that the capture ELISA assay was unable to detect small amounts of p57 aggregates in ECP, or perhaps denaturing conditions are necessary for aggregation. P57 has been described to form short, flexible, $<2 \mathrm{~nm}$ diameter fimbriae that extend beyond the polysaccharide capsule (Dubreuil et al. 1990a,b). Presently, 
the relationship between fimbrae, cell associated p57, and the secreted p57 in ECP is unclear. The monomers in ECP may result from proteolysis or unfolding of a dimer or multimer on the bacterial cell surface.

To independently determine the native molecular weight of $p 57$ in the absence of apparent denaturation, p57 was purified from ECP using ion-exchange and size exclusion chromatography. P57 was partially purified and eluted with a $M_{\mathrm{r}}$ of 46500 consistent with a monomeric structure. The estimated relative molecular mass was smaller than the molecular mass of 54505 Da calculated from the amino acid sequence of the mature protein (Chien et al. 1992). The reason for this discrepancy is unknown. A small amount of p45 breakdown product was present (Fig. 6, lane 3), however, the majority of p57 in our analysis appears identical to p57 in unfractionated ECP by Western blot, suggesting that difference in migration was not due to extensive proteolysis during purification. Possibly p57 exhibits a compact structure under nondenaturing conditions. Secondary amino acid structure prediction supports this possibility as p57 is composed of predominatly beta-regions with little alpha-helix (unpubl. data).

Since a number of agglutinins are multimeric structures, yet p57 eluted as a monomer, the biological activity was tested in both haemagglutination and leucoagglutination assays. In vitro addition of the partially purified p57 monomer to rainbow trout leucocytes and rabbit erythrocytes was sufficient to cause agglutination and the activity was increased 2 -fold by purification. The small increase in biological activity after purification was not unexpected as p57 is the major component of Renibacterium salmoninarum ECP (Getchell et al. 1985, Wiens \& Kaattari 1991, Barton et al. 1997). The agglutinating activity was specific to p57 as it was blocked by MAb 4H8. Interestingly, capture ELISA analysis suggested that a monomer was also the predominant from of p57 in kidney homogenates from 3 naturally-infected adult chinook salmon. From these data we propose a model of p57 in which, at least initially, a monomer is sufficient to initiate agglutinating activity and is released by $R$. salmoninarum during in vivo infection.

Assuming that p57 agglutinates cells in a receptorspecific manner, we propose 3 potential mechanisms of p57 monomer-mediated agglutination. In the first mechainsm, p57 may initially be a monomer but may dimerize or aggregate after binding to a eucaryotic cell receptor. The binding site on p57 is likely located on the amino-terminal portion of p57 as MAbs that block agglutination bind this region. Once initial binding to the leucocyte occurs, the carboxy-region could be exposed. The exposed portions of $\mathrm{p} 57$ on adjacent leucocytes or erythrocytes might then dimerize or multimerize resulting in agglutination. While there is no direct evidence of the carboxy-region facilitating aggregation, p57 can aggregate after exposure to denaturing conditions (Barton et al. 1997). In addition, secreted p57 is capable of reassembly onto the Renibacterium salmoninarum cell surface (Daly \& Stevenson 1990 Piganelli et al. 1999a). The carboxy-terminal portion has been implicated in attachment to the bacterial cell surface as partial proteolysis of p57 leaves carboxy-terminal fragments but not amino-terminal fragments associated with the bacterium (Wiens \& Kaattari 1991).

A second possible mechanism of monomer-mediated agglutination may be via proteolysis of host cell surface receptors. Haemagglutinins from both Vibrio cholerae and Pseudomonas aeruginosa have zinc/calcium dependent proteolytic activity that is able to modify erythrocyte surfaces and thereby induce agglutination (Hase \& Finkelstein 1990). This mechanism requires p57 to posess proteolytic activity. Lynch and collegues have demonstrated that p57, and several lower molecular weight products of $p 57$, continue to degrade during 2-dimensional electrophoretic separation of ECP (Griffiths \& Lynch 1991, Barton et al. 1997). Furthermore, p57, and degradation products of $p 57$ isolated from the WC strain of Renibacterium salmoninarum, comigrate with PMSF-sensitive proteolytic activity detected by gelatin substrate gels. Taken together these results suggests that p57 is autoproteolytic (Barton et al. 1997). Sequence analysis of p57 is consistent with this possibility as there is homology between the second repeated region of p57 and both trypsin-like and V8 staphylococcal-type serine proteases (Chien et al. 1992). In addition, a consensus serine protease motif G-X-S-X-G has been located from Gly-406 and Gly-410 between repeats B2 and B3 (Fig. 2A) (Grayson et al. 1995). We however have previously failed to detect autoproteolytic activity of p57 purified by isoelectric focusing from the ATCC 33209 and D6 strains (Rockey et al. 1991b), though as Barton et al. (1997) point out, this could be due to inactivation of proteolytic activity during isoelectric focusing. While we did not initially design these experiments to investigate the autoproteolytic activity of p57, our main finding was that agglutinating activity did not elute with azoalbumin proteolytic activity suggesting that the azoalbumin proteolytic activity is a distinct molecule from p57. In addition, the agglutinating activity of ECP was not inhibited by PMSF or EDTA suggesting that neither serine nor divalent cation dependent proteolytic activity is required for agglutination (G. D. Wiens unpubl. data). The presence of a protease in ECP separate from p57 is consistent with our previous observations that ECP incubated at $37^{\circ} \mathrm{C}$ contains a molecule of $>100 \mathrm{kDa}$ that is PMSF-sensitive with proteolytic activity but no detectable p57 (Rockey et al. 
1991). In addition, the molecule having proteinase activity had an isoelectric point between 6.5 and 7.5 which is distinct from the 4.5 isoelectric point of p57 (Rockey et al. 1991). In summary, our data argue against a protease dependent model of agglutination, though the role of the G-X-S-X-G serine protease motif in agglutination remains to be formally tested by sitedirected mutagenesis.

A third mechanism whereby p57 agglutinates cells maybe via the recognition and cross-linking of different cellular receptors. It is possible that 2 separate agglutinating domains exist, each specific for a separate receptor. Results from the antigen capture ELISA provides potential evidence for this model as MAbs $4 \mathrm{C} 11$ and $4 \mathrm{H} 8$, which are able to inhibit leucoagglutinating activity, bind to separate epitopes. Superantigens, many which are produced by Gram-positive bacteria, have such bifunctional properties and are able to bind and crosslink both major histocompatibility class II molecules and T cell receptors (Seth et al. 1994). P57 is unlike other superantigens from Gram-positive bacteria as, to our knowledge, superantigens from Grampositive bacteria do not agglutinate erythrocytes (Johnson et al. 1991). Support for this mechanism awaits analysis of the mitogenic activity of purified $\mathrm{p} 57$ and the identification of the leucocyte surface recep$\operatorname{tor}(s)$.

In summary, we demonstrate that agglutination-neutralizing group I MAbs recognize separate epitopes on the amino-terminal portion of $\mathrm{p} 57$ and that a monomer is the predominant subunit structure of p57 in ECP and in infected fish tissue. The role of the monmeric p57 in pathogensis is unclear. One cellular target of p57 may be salmonid leukocytes where it may down regulate immune function of the salmonid host leading to a nonproductive response. In support of this possibility, p57 inhibits specific antibody production in vitro (Turaga et al. 1987a, Rockey et al. 1991b, and Wiens \& Kaattari 1991, Fredriksen et al. 1997) and injection of p57 into coho salmon eggs results in long term immunosuppression (Brown et al. 1996). The presence of bacterial cell-associated p57 is also likely to be critical in pathogensis as the creation of $\mathrm{p} 57^{-}$cells by the activation of an endogenous PMSF-senstive protease leads to an increased humoral response toward carbohydrate moieties on the bacterial cell surface (Wood \& Kaattari 1996, Piganelli et al. 1999a). In addition, results from preliminary vaccine trials using $37^{\circ} \mathrm{C}$ treated Renibacterium salmoninarum cells suggest that the removal of p57 is critical for the induction of protective immunity in salmonids (Piganelli et al. 1999b). The future analysis of p57 mutants should facilitate the characterization of functional domain(s) and may clarify how the presence of p57 impairs the development of protective immunity in salmonids.
Acknowledgements. Support for this research was received in part from Grant DE-FG79-89BP95906 from the Bonneville Power Administration to S.L.K., and from Grant number NA89AA-D-SG022, Project R/A-56 from the National Oceanic and Atmospheric Administration to the Washington Sea Grant Program. We thank Drs B. Wiens and D. Rockey for their critical review of this manuscript, and $J$. Bishop and M. Howell for help with FPLC fractionation.

\section{LITERATURE CITED}

Bandin I, Santos Y, Magarinos B, Barja JL, Toranzo AE (1992) The detection of two antigenic groups among Renibacterium salmoninarum isolates. FEMS Microbiol Lett 94: $105-110$

Barton TA, Bannister LA, Griffiths SG, Lynch WH (1997) Further characterization of Renibacterium salmoninarum extracellular products. Appl Environ Microbiol 63:3770-3775

Brown LL, Iwama GK, Evelyn TPT (1996) The effect of early exposure of coho salmon (Oncorhynchus kisutch) eggs to the P57 protein of Renibacterium salmoninarum on the development of immunity to the pathogen. Fish Shellfish Immunol 6:149-165

Bruno DW (1988) The relationship between auto-agglutination, cell surface hydrophobicity and virulence of the fish pathogen Renibacterium salmoninarum. FEMS Microbiol Lett 51:135-140

Bruno DW (1990) Presence of a saline extractable protein associated with virulent strains of the fish pathogen Renibacterium salmoninarum. Bull Eur Assoc Fish Pathol 10: $8-10$

Bruno DW, Munro ALS (1986) Observations on Renibacterium salmoninarum and the salmonid egg. Dis Aquat Org 1:83-87

Chien MS, Gilbert TL, Huang C, Landolt ML, O'Hara PJ, Winton JR (1992) Molecular cloning and sequence analysis of the gene coding for the 57-KDa major soluble antigen of the salmonid fish pathogen, Renibacterium salmoninarum. FEMS Microbiol Lett 96:259-266

Daly JG, Stevenson RM (1990) Characterization of the Renibacterium salmoninarum haemagglutinin. J Gen Microbiol 136:949-953

DeKoning JD, Kaattari SL (1991) Mitogenesis of rainbow trout peripheral blood lymphocytes requires homologous plasma for optimal responsiveness. In Vitro Cell Dev Biol 27 : $381-386$

Dubreuil JD, Jacques M, Graham L, Lallier R (1990a) Purification, and biochemical and structural characterization of a fimbrial haemagglutinin of Renibacterium salmoninarum. J Gen Microbiol 136:2443-2448

Dubreuil JD, Lallier R, Jacques M (1990b) Immunoelectron microscopic demonstration that Renibacterium salmoninarum is encapsulated. FEMS Microbiol Lett 66:313-316

Elliott DG, Pascho RJ, Bullock GL (1989) Developments in the control of bacterial kidney disease of salmonid fishes. Dis Aquat Org 6:201-215

Evelyn TPT, Ketcheson JE, Prosperi-Porta L (1984) Further evidence for the presence of Renibacterium salmoninarum in salmonid eggs, and for the failure of povidone-iodine to reduce the intro-ovum infection rate in water-hardened eggs. J Fish Dis 7:173-182

Evelyn TPT, Ketcheson JE, Prosperi-Porta L (1986) Experimental intra-ovum infection of salmonid eggs with Renibacterium salmoninarum and vertical transmission of the pathogen with such eggs despite their treatment with erythromycin. Dis Aquat Org 1:197-202 
Evenden AJ, Grayson TH, Gilpin ML, Munn CB (1993) Renibacterium salmoninarum and bacterial kudney diseasethe unfinished jigsaw. Annu Rev Fish Dis 3:87-104

Fredriksen A, Endresen C, Wergeland HI (1997) Immunosuppressive effect of a low molecular weight surface protein from Renibacterium salmoninarum on lymphocytes from Atlantic salmon (Salmo salar L.). Fish Shellfish Immunol 7 : $273-282$

Fryer JL, Sanders JE (1981) Bacterial kidney disease of salmonid fish. Annu Rev Microbiol 35:273-298

Getchell RG, Rohovec JS, Fryer JL (1985) Comparison of Renibacterium salmoninarum isolates by antigenic analysis. Fish Pathol 20:149-159

Grayson TH, Evenden AJ, Gilpin ML, Munn CB (1995) Production of the major soluble antigen of Renibacterium salmoninarum in Escherichia coli K12. Dis Aquat Org 22: $227-231$

Griffiths SG, Lynch WH (1991) Instability of the major soluble antigen produced by Renibacterium salmoninarum. J Fish Dis 14:55-56

Gutenberger SK, Duimstra RJ, Rohovec JS, Fryer JL (1997) Intracellular survival of Renibacterium salmoninarum in trout mononuclear phagocytes. Dis Aquat Org 28:93-106

Hase CC, Finkelstein RA (1990) Comparison of the Vibrio cholerae hemagglutinin/protease and the Pseudomonas aeruginosa elastase. Infect Immun 58:4011-4015

Hsu HM, Bowser PR, Schachte JH (1991) Development and evaluation of a monoclonal-antibody-based enzyme-linked immunosorbent assay for the diagnosis of Renibacterium salmoninarum infection. J Aquat Anim Health 3:168-175

Johnson HM, Russel JK, Pontzer CH (1991) Staphylococcal enterotoxin microbial superantigens. FASEBJ 5:2706-2712

Jones GW, Isaacson RE (1983) Proteinaceous bacterial adhesins and their receptors. CRC Crit Rev Microbiol 10:229-260

Lowry OH, Rosebrough NJ, Farr DL, Randall RJ (1951) Protein measurement with the Folin phenol reagent. J Biol Chem 193:255-276

McIntosh D, Flano E, Grayson TH, Gilpin ML, Austin B, Villena A.J (1997) Production of putative virulence factors by Renibacterium salmoninarum grown in cell culture. Microbiology 143:3349-3356

Piganelli JD, Wiens GD, Kaattari SL (1999a) Elevated temperature treatment as a novel method for decreasing p57 on the cell surface of Renibacterium salmoninarum. Dis

Editorial responsibility: David Bruno,

Aberdeen, Scotland, UK
Aquat Org 36:29-35

Piganelli JD, Wiens GD, Zhang JA, Christensen JM, Kaattari SL (1999b) Evaluation of a whole cell, p57-vaccine against Renibacterium salmoninarum. Dis Aquat Org 36:37-44

Rockey DD, Gilkey LL, Wiens GD, Kaattari SL (1991a) Monoclonal antibody based analysis of the Renibacterium salmoninarum P57 protein in spawning chinook and coho salmon. J Aquat Anim Health 3:23-30

Rockey DD, Turaga PSD, Wiens GD, Cook BA, Kaattari SL (1991b) Serine proteinase of Renibacterium salmoninarum digests a major autologous extracellular and cell-surface protein. Can J Microbiol 37:758-763

Sarath G, De La Motte RS, Wagner RW (1989) Protease assay methods. In: Beyon RJ, Bond JS (eds) Proteolytic enzymes: a practical approach. IRL Eynsham, Oxford, p 25-55

Seth A, Stern LJ, Ottenhoff THM, Engel I, Owen MJ, Lamb JR, Klausner RD, Wiley DC (1994) Binary and ternary complexes between $\mathrm{T}$ cell receptor, Class II MHC and superantigen in vitro. Nature 369:324-327

Turaga P, Wiens G, Kaattari S (1987a) Bacterial kidney disease: the potential role of soluble protein antigen(s). J Fish Biol 31 (Suppl A):191-194

Turaga PSD, Wiens GD, Kaattari SL (1987b) Analysis of Renibacterium salmoninarum antigen production in situ. Fish Pathol 22:209-214

Wiens GD, Kaattari SL (1989) Monoclonal antibody analysis of common surface protein(s) of Renibacterium salmoninarum. Fish Pathol 24:1-7

Wiens GD, Kaattari SL (1991) Monoclonal antibody characterization of a leukoagglutinin produced by Renibacterium salmoninarum. Infect Immun 59:631-637

Wiens GD, Turaga PSD, Kaattari SL (1990) Western blot analysis of a fish pathogen. In: Stolen JS, Fletcher TC, Anderson DP, Roberson BS, van Muiswinkel WB (eds) Techniques in fish immunology. SOS Publications, Fair Haven, p 87-94

Wood PA, Kaattari SL (1996) Enhanced immunogenicity of Renibacterium salmoninarum in chinook salmon after removal of the bacterial cell surface-associated $57 \mathrm{kDa}$ protein. Dis Aquat Org 25:71-79

Young CL, Chapman GB (1978) Ultrastructural aspects of the causative agent and renal histopathology of bacterial kidney disease in brook trout (Salvelinus fontinalis). J Fish Res Bd Can 35:1234-1.248

Submitted: June 26, 1998, Accepted: January 13, 1999

Proofs received from author(s): June 7, 1999 